\title{
The Latitudinal Analysis of Secondary School Students' Motivations towards Science Course
}

\author{
Suleyman Aydin*, Pinar Ural Keles \\ Faculty of Education, Ibrahim Çeçen University of Agri, Turkey
}

Copyright $\bigcirc 2017$ by authors, all rights reserved. Authors agree that this article remains permanently open access under the terms of the Creative Commons Attribution License 4.0 International License

\begin{abstract}
The aim of this research was to investigate the comparison of different categories of secondary schools students' motivations for science lessons. In this research, the case study method was used latitudinally and it was carried out in the center schools of Agri in 2015-2016 academic years. The sample of the study was composed of totally 649 students; 161 students from $5^{\text {th }}$ Class, 174 from $6^{\text {th }}$ class, 152 from $7^{\text {th }}$ class and 162 from $8^{\text {th }}$ class. A 'Motivation Scale Test' taken from the literature was used as data collection tool in the study. Cronbach Alpha reliability coefficient of the test was recalculated as 0,77 by applying it on $1156^{\text {th }}$ grade students. SPSS 21,0 program was used to analyze the data and the results were assessed on 0,05 significant level of independent t-test. In the study, it was determined that the average points of students' motivation were getting smaller while their class level getting bigger. In the study, the decrease between the consecutive class levels was not found statistically significant $\left(5^{\text {th }}\right.$ and $6^{\text {th }} \mathrm{p}>0,05 ; 6^{\text {th }}$ and $7^{\text {th }} p>0,05 ; 7^{\text {th }}$ and $\left.8^{\text {th }} p>0,05\right)$, but the difference between $5^{\text {th }}$ class and $8^{\text {th }}$ class students' average motivation points was found statically significant $(\mathrm{p}=0.017 ; \mathrm{p}<0,05)$.
\end{abstract}

Keywords Secondary School Students, Science Course, Motivation

\section{Introduction}

It is well-known that it is important to make students acquire cognitive properties as well as affective properties in today's educational system (Tuan et al., 2005). It has been reported in studies that affective field skills are an important factor in making students become successful (Duit \& Treagust, 2003; Tuan, et al., 2005; Dede \&Yaman, 2008). For this reason, the success of the Science Education Classes Educational Curriculum, which was updated in 2013, has been based on the realization of the acquisitions in the fields of "Knowledge", "Skill", "Perception", and
"Science-Technology-Society-Environment (STSE)" (MoNE, 2013). The perception learning field in science education classes consists of "attitude", "motivation", "value" and "responsibility" sub-learning fields (MoNE, 2013). The scope of the motivation, which is one of these sub-learning fields, consists of "being willing to work in studies conducted on science, and participating in these studies voluntarily" (MoNE, 2013).

When learning is explained as a behavioral change, it is known that motivation is necessary for a change in behaviors (Sevinc et al., 2011). As a matter of fact, when motivated individuals are inclined to deal with learning activities (Zimmerman, 2000); the ones that are not motivated at an adequate level are not ready for learning (Selcuk, 2000; Ulusoy, 2007). In addition, students with high motivation levels are inclined to show more effort and resolution within the classroom in intra-class activities and tasks when compared with the students with lower motivation levels (Wolters \& Rosenthal, 2000, Martin, 2001). For this reason, the academic success of a student who has high motivation is also at a higher level (Senemoglu, 2007).

Student motivation is also one of the key concepts in science education (Bonney et al., 2005). It has been reported in previous studies that there would be increases in the success levels in science education when students are supported by addressing their affective fields (Butler, 2009; Guvercin et al., 2010; Sevinc et al., 2011). According to Hoang (2007), it is difficult to ensure the motivation of students in science education; however, it is necessary for an efficient science education. Tuan et al. (2005) examined the effect of science motivations of students on cognitive learning, and reported six factors that influenced the student motivation towards learning science as self-sufficiency, active learning strategies, the value of learning science, performance targets, success targets and the motivation of the learning environment. In another study, it was reported that the participation of students in science classes stemmed from some internal and external reasons, and this situation was associated with motivation. In some students, the feeling of curiosity for scientific 
concepts is in the forefront and for this reason these students struggle to discover and learn (internal motivation); while some other students may act with the consideration of being at upper levels in terms of social status among their peers (external motivation) (Belo et al., 2009). In addition, it is known that the knowledge and experience of students may be used to increase their motivations in learning science. According to Butler (2009), the awareness of a student on the pollution that occur in the area where s/he lives as a result of intense transportation, and the physical and chemical changes may be the starting point in increasing the desire of the student to learn science. It has been reported that the students who are well-motivated to science classes will find the subjects that are taught in classes entertaining (internal motivation), will be interested in certain subjects (personal interest), will form the desire to understand the subject, and therefore, will participate in the class in an active manner (Cimen, 2007).

On the other hand, it has also been reported that the motivations of students in science classes are influenced by some variables like individual properties, teaching methods and techniques, learning medium and teaching curriculum (Yilmaz and Cavas, 2007; Ng et al., 2010). In the science curriculum, which was updated in 2013, motivation was included in the curriculum for the first time as a separate learning field (MoNE, 2013). As a matter of fact, it was known that the affective dimension of science and technology teaching was not included in the curriculum at an adequate level, and the curriculum was weak on this point (Cil and Cepni, 2009). For this reason, it is a curious area how adding the motivation dimension to the Science Education curriculum influenced the motivations of secondary school students in the subjects in science classes. Although there are a great deal of studies in the literature that reveal the influence of motivation on science education (Waters and Ginns, 2000; Hynd, et al, 2000; Tuan, et al, 2005; Y1lmaz and Cavas, 2007; Hoang, 2007; Dede and Yaman, 2008; Butler, 2009; Nbina, 2010; Guvercin et al., 2010; Sevinc et al., 2011), there are no studies conducted on how the updated science education curriculum influenced the motivation of secondary school students in science education. The purpose of this study is to examine the motivations of students who are studying at various levels of secondary schools in science classes.

\section{Method}

The Special Case method was used in this study. This method was made use of in order to examine the problem in detail (Cepni and Cil, 2009). The study was conducted in latitudinal design. In such studies, the study is conducted and completed on the sampling that may be equal to the universe throughout the lifespan in different years (Cepni, 2009).

\subsection{Sample}

The sampling of the study consists of 161 students from $5^{\text {th }}$ Grades; 174 students from $6^{\text {th }}$ Grades; 152 students from $7^{\text {th }}$ Grades; and 162 students from $8^{\text {th }}$ Grades, 649 students in total, who studied at secondary schools in the city of Agri city center in 2015-2016 Academic year.

\subsection{Data Collection Instrument}

The "Motivation Scale", which was prepared by Dede and Yaman (2008), was used in this study. The Internal Consistency Coefficient of this scale, which is used by many researchers, was found as 0,80 . The scale, which was prepared in the form of 5-Point Likert Design and aimed to determine the motivation levels of students, included 23 items in total consisting of 2 negative items $\left(10^{\text {th }}\right.$ and $23^{\text {rd }}$ Items), and 21 positive items. The items in the Motivation Scale were separated into 5 sub-factors. These factors were grouped as; the motivation on conducting research, the motivation on performance, the motivation on communication, the motivation on cooperative work, and the motivation on participation (Dede and Yaman, 2008).

There are statements like "I definitely agree", "I agree", "I am indecisive", "I do not agree", "I definitely disagree" opposite each statement in the scale to enable students reflect their ideas on that statement. The positive statements were given $5,4,3,2,1$ points, and the negative statements were given 1, 2, 3, 4, 5 points, and the points given to each statement were added to determine the points of the students; and the highest point that may be received from the scale was defined as 115 .

Before the Motivation Scale, which belongs to Dede and Yaman (2008), was used in this study, the Cronbach Alpha Internal Consistency Coefficient of the scale was re-calculated. For this purpose, the scale was applied to 115 Sixth Grade students again, and the data obtained after this application were analyzed in SPSS 21,0 Package program. The Cronbach Alpha Internal Consistency Coefficient of the test was calculated as 0,77 . Kalayci (2005) stated that the scales that have the values like $.60 \leq \alpha<.80$ are "extremely reliable".

\subsection{Data Analysis}

In the analysis of data obtained from the study the SPSS 21.0 packet program was used. The data were analyzed using independent t-test and evaluated at the level of 0.05 significant level.

\section{Findings}

In the study, secondary school $5^{\text {th }}$ and $6^{\text {th }}$ class students' average points of science motivations were compared using independent t-test and the data obtained from the study were given in Table 1. 
Table 1. The independent $t$ - test results for comparison of secondary school $5^{\text {th }}$ and $6^{\text {th }}$ class students' average scores of science motivations

\begin{tabular}{|c|c|c|c|c|c|}
\hline Groups & $\mathbf{N}$ & $\mathbf{X}$ & SD & T & $\mathbf{p}$ \\
\hline $\mathbf{5}^{\text {th }}$ class & 161 & 94,92 & 48,56 & 1,88 & 0,071 \\
\hline $\mathbf{6}^{\text {th }}$ class & 174 & 87,87 & 8,44 & & \\
\hline
\end{tabular}

${ }^{*} \mathrm{p}>0,05$

As seen in the table 1 while $5^{\text {th }}$ class students' motivation points for science were $94,92,6^{\text {th }}$ class students' motivation points were found to be 87,87 over 115. At the end of the t-test results between the $5^{\text {th }}$ class students' grades and $6^{\text {th }}$ class students' grades, 7,05 difference found in favor of $5^{\text {th }}$ class, has not been found statistically significant $(\mathrm{p}=0,071>0,05)$.

$6^{\text {th }}$ and $7^{\text {th }}$ class students' average points of science motivations were compared using independent $\mathrm{t}$ - test and the data obtained from the study were given in table 2 .

Table 2. The independent t- test results for comparison of secondary school $6^{\text {th }}$ and $7^{\text {th }}$ class students' average scores of science motivations

\begin{tabular}{|c|c|c|c|c|c|}
\hline Groups & $\mathbf{N}$ & $\mathbf{X}$ & SD & $\mathbf{T}$ & $\mathbf{p}$ \\
\hline $\mathbf{6}^{\text {th }}$ class & 174 & 87,87 & 8,44 & 4,47 & $\mathrm{p}=0,063$ \\
\hline $\mathbf{7}^{\text {th }}$ class & 152 & 87,43 & 8,53 & & \\
\hline
\end{tabular}

$* \mathrm{p}>0,05$

As seen in the table 2 while $6^{\text {th }}$ class students' motivation points for science were $87,87,6^{\text {th }}$ class students' motivation points were found to be 87,43 . T-test results between the $6^{\text {th }}$ class students' grades and $7^{\text {th }}$ class students' grades, 0,44 difference found in favor of $6^{\text {th }}$ class, has not been found statistically significant $(\mathrm{p}=$ $0,063>0,05)$.

$7^{\text {th }}$ and $8^{\text {th }}$ class students' average points of science motivations were compared using independent $\mathrm{t}$ - test and the data obtained from the study were given in table 3 .

Table 3. The independent t- test results for comparison of secondary school $7^{\text {th }}$ and $8^{\text {th }}$ class students' average scores of science motivations

\begin{tabular}{|l|c|c|c|c|c|}
\hline Groups & $\mathbf{N}$ & $\mathbf{X}$ & SD & $\mathbf{T}$ & $\mathbf{p}$ \\
\hline $\mathbf{7}^{\text {th }}$ class & 152 & 87,43 & 8,53 & & 0,056 \\
\hline $\mathbf{8}^{\text {th }}$ class & 162 & 85,60 & & & \\
\hline
\end{tabular}

$* \mathrm{p}>0,05$

As seen in the table 3 while $7^{\text {th }}$ class students' motivation points for science were $87,43,8^{\text {th }}$ class students' motivation points were found to be 85,60 . T-test results between the $7^{\text {th }}$ class students' grades and $8^{\text {th }}$ class students' grades, 1,83 difference found in favor of $7^{\text {th }}$ class, has not been found statistically significant $(\mathrm{p}=$ $0,056>0,05)$.

Secondary school $5^{\text {th }}$ and $8^{\text {th }}$ class students' average points of science motivations were compared using independent t-test and the data obtained from the study were given in table 4 .
Table 4. The independent t- test results for comparison of secondary school $5^{\text {th }}$ and $8^{\text {th }}$ class students' average scores of science motivations

\begin{tabular}{cccccc}
\hline Groups & $\mathbf{N}$ & $\mathbf{X}$ & SD & T & p \\
\hline $\mathbf{5}^{\text {th }}$ class & 161 & 94,92 & 48,56 & & 0.017 \\
\hline $\mathbf{8}^{\text {th }}$ class & 162 & 85,60 & & & \\
\hline
\end{tabular}

$* \mathrm{p}>0,05$

As seen in table 4 It has been found a decrease between the average scores of the $5^{\text {th }}$ and $8^{\text {th }}$ class students in secondary school as 9,32 . And it has been found that this decrease in the students' average points were statistically meaningful $(\mathrm{p}=0.017 ; \mathrm{p}<0,05)$.

\section{Result and Discussion}

In this study, which was conducted to examine the motivations of the students studying at various levels of secondary school in science classes, it was determined that the average points received from the motivation scale by the students over maximum 115 points were distributed as follows; for $5^{\text {th }}$ Grades, 94,92; for $6^{\text {th }}$ Grades, 87,87; for $7^{\text {th }}$ Grades, 87,43; and for $8^{\text {th }}$ Grades, 85,60 . When the data obtained in the study are examined it is possible to suggest that the average of the Science Motivation Points received by the students in all grades of the secondary school is at a high level (23.00-53.66: low, 53.67-84.32: medium, 84.33-115.00: high). In previous studies conducted on the former Science and Technology Education Curriculum, it was also reported that the average of the science motivation points was high. Uzun \& Keles (2012), Yaman \& Dede, (2007), Guvercin, (2008), Yenice, Saydam \& Telli (2012) conducted studies and reported that the motivation levels of the students were also high.

Although the average of the science motivation points of the students has been determined to be generally high in the present study, it is also observed that as the grade levels of the students rise, the average points decrease, and the highest decrease is observed to be between the $5^{\text {th }}$ and $6^{\text {th }}$ Grades with 7.05 points. This decrease was determined to be 0.44 points between the $6^{\text {th }}$ Grades and $7^{\text {th }}$ Grades, while it was determined to be 1.83 points between the $7^{\text {th }}$ and $8^{\text {th }}$ Grades. In the statistical analyses, it was determined that the decrease observed in the averages of the science motivation points of the students as the grade increased was not significant in all grades $(5$ and $6 p>0,05 ; 6$ and 7 $p>0,05 ; 7$ and $8 p>0,05)$. Based on these points, it may be suggested that there are no changes in average Science Motivation Points of the secondary school students when they pass on to an upper grade. On the other hand, it was also determined that the 9.32-point decrease in the average motivation points of the students observed from the $5^{\text {th }}$ Grade until the $8^{\text {th }}$ Grade was statistically significant $(p=0.017 ; p<0,05)$. Based on this point, it may be concluded that the average Science Motivation Points of the students decrease throughout the secondary school education. There are studies in the literature reporting different results in this 
field. Yaman and Dede (2007), Ekici et al., (2014) conducted studies and determined that the motivations of the students from lower grades had higher motivations on science education than the students from other grades. Uzun and Keles (2010) conducted a study and reported that the motivations of secondary school students did not vary according to grades. It is considered that these different results stem from the study groups and the curricula being different.

In the present study, although the decrease observed in the average science motivation points of the students is not statistically significant, it arouses concerns in scientists. Especially the decrease observed in this study between $5^{\text {th }}$ and $6^{\text {th }}$ Grades at a rate of 7.05 points is extremely important. This trend of decrease extends from $5^{\text {th }}$ Grade till $8^{\text {th }}$ Grade, which was determined to be 9.32 points in the $8^{\text {th }}$ Grade. Although the motivation dimension was added to the Science Education Curriculum, the significant decrease in average motivation levels of the students may be explained with the lack of adequate acknowledgement of updated science curriculum by teachers, and the lack of application of the activities in the curriculum. As a matter of fact, it was reported in the study conducted by Karaman \& Karaman (2016) that adequate information has not been given to the teachers on the updated science education curriculum, and the curriculum was not understood well. Ciray et al. (2015) conducted another study on the viewpoints of the teaches on Science Education Curriculum and reported that the teachers stated that it was not clear what was expected from the teachers, the participant teachers stated that they did not have information on how to apply the new curriculum, and the teaching-learning time was inadequate.

In addition, it has also been reported in studies that crowded classes and the inadequate resources in the laboratories are the most important obstacles that prevent the student-centered activities given in science education curriculum. (Toraman \& Alci, 2013; Karaman \& Karaman, 2016). Ciray et al., (2015) conducted another study and reported that the participant teachers complained especially about the lack of sample applications in teaching-learning processes. It is already known that student-centered applications are extremely important in raising the science motivations of students ( $\mathrm{Ng}$ et al., 2010).

Organizing in-service training courses by considering the four basic dimensions of the program intended especially for Science Education teachers will ensure that teachers will recognize the educational curriculum in an adequate manner, and this will also contribute to complete the missing points on the topic.

\section{REFERENCES}

[1] Belo, N. A. H., Driel, J. H. \& Verloop, N. (2010). Teachers' beliefs about making physics angaging and comprehensible for secondary students in the Netherlands. In M.F. Taşar \& G. Çakmakcı (Eds.), Contemporary science education research: teaching (pp. 29 - 93). Ankara, Turkey: Pegem Akademi

[2] Butler, M. B. (2009). Motivating Young Students to be Successful in Science: Keeping It Real, Relevant and Rigorous. National geographic, July.

[3] Çepni, S. (2009). Araştırma ve Proje Çalışmalarına Giriş (Gözden geçirilmiş baskı). Trabzon: Celepler Matbaacılık

[4] Çepni, S. ve Çil, E. (2009). Fen ve Teknoloji Programı İlköğretim 1. Ve 2. Kademe Öğretmen El Kitabı. Pegem Akademi Yayınları.

[5] Çimer, A. (2007). Effective Teaching in Science: A Review of Literature. Journal of Turkish science education, 4(1), 20-44.

[6] Çıray, F., Küçükyılmaz E.A. ve Güven M. (2015). Ortaokullar İçin Güncellenen Fen Bilimleri Dersi Öğretim Programına İlişkin Öğretmen Görüşleri. Dicle üniversitesi Ziya Gökalp Eğitim Fakültesi Dergisi, 25, 31-56

[7] Dede, Y. \& Yaman, S. (2008). Fen Öğrenmeye Yönelik Motivasyon Ölçeği: Geçerlik ve Güvenirlik Çalışması. Necatibey Eğitim Fakültesi Elektronik Fen ve Matematik Eğitimi Dergisi (EFMED) 2(1), 19-37.

[8] Duit, R. \& Treagust, D. (2003). Conceptual change: A powerful framework for improving science teaching and learning. International Journal of Science Education, 25(6), 671-688.

[9] Ekici D., Kaya K \& Mutlu O., (2014) Ortaokul ögrencilerinin fen öğrenmeye yönelik motivasyonlarının farklı değişkenlere göre incelenmesı: Uşak İli Örneği, Mersin Üniversitesi Eğitim Fakültesi Dergisi Cilt 10, Sayı 1.

[10] Güvercin, Ö. (2008). Investigating elementary students' motivation towards science learning: A cross age study. Yayınlanmamış Yüksek Lisans Tezi, Ortadoğu Teknik Üniversitesi, Ankara.

[11] Hoang, T. (2007). Creativity: A Motivational Tool for Interest and Conceptual Understanding in Science Education. International Journal of Human and Social Sciences 2(8), 477-483.

[12] Hynd, C., Holschuh J. \& Nist, S. (2000). "Learning complex scientific information: Motivation theory and its relation to student perceptions". Reading\&Writing Quarterly, 16, 2357.

[13] Kalaycı, Ş. (2005). SPSS Uygulamalı Çok Değişkenli İstatistik Teknikleri, Asil Yayın Dağıtım, Ankara

[14] Karaman\&Karaman (2016). Fen bilimleri öğretmenlerinin yenilenen fen bilimleri öğretim programına yönelik görüşleri, Erzincan Üniversitesi Eğitim Fakültesi Dergisi Cilt 18, Say1 1.

[15] Martin, A. J. (2001). The student motivation scale: A tool for measuring and enhancing motivation. Australian Journal of Guidance and Counselling, 11, 11-20.

[16] MEB. (2013). İlköğretim kurumları ilkokullar ve ortaokullar fen bilimleri dersi $(3,4,5,6,7$ ve 8 . sinıflar) öğretim programı, Milli Eğitim Bakanlığı Ankara. 
[17] Nbina, J. B. (2010). Re-visiting Secondary School Science Teachers Motivation Strategies to face the Challenges in the 21st Century. Academic leadership live, online journal, 8(4).

[18] Ng, K.T., Soon, S.T. \& Fong, S.F. (2010). Development of a Questionnaire to Evaluate Students' Perceived Motivation towards Science Learning Incorporating ICT Tool. Malaysian Journal of Educational Technology, 10(1), 39-55.

[19] Selçuk, Z. (2000). Gelişim Ve Öğrenme, Geliştirilmiş 7. Baskı. Ankara: Nobel Yayınları.

[20] Senemoğlu, N. (2007). Gelişim Öğrenme ve Öğretim Kuramdan Uygulamaya Ankara:Gönül Yayıncılık

[21] Sevinç, B., Özmen, H. \& Yiğit, N. (2011). Investigation of primary students' motivation levels towards science learning. Science Education International, 22(3), 218-232.

[22] Toraman, S. ve Alc1, B. (2013). Fen ve Teknoloji Öğretmenlerinin Yenilenen Fen Bilimleri Dersi Öğretim Programına İlişkin Görüşleri, EKEV Akademi Dergisi, 17 (56), 11-22.

[23] Tuan, Chin \& Shieh (2005). The development of a questionnaire to measure students' motivation towards science learning. International Journal of Science Education, Vol 27(6), 634-659.

[24] Ulusoy, A. (2007). Eğitim Psikolojisi, Ankara: Anı yayıncilik.

[25] Uzun, N. ve Keleş, Ö. (2010). Fen öğrenmeye yönelik motivasyonun bazı demografik özelliklere göre değerlendirilmesi. Gazi Eğitim Fakültesi Dergisi, 30(2), 561-584.

[26] Watters, J. J. and Ginns, I. S. (2000). Developing motivation to teach elementary science: effect of collaborative and authentic learning practices in preservice education. Journal of Science Teacher Education, 11(4), 277-313.

[27] Wolters, C.A., \& Rosenthal, H. (2000). The relation between students' motivational beliefs and their use of motivational regulation strategies. International Journal of Educational Research, 33, 801-820.

[28] Yaman, S. ve Dede, Y. (2007). Öğrencilerin fen ve teknoloji ve matematik dersine yönelik motivasyon düzeylerinin bazı değişkenler açısından incelenmesi. Kuram ve Uygulamada Eğitim Yönetimi, (52), 625-638.

[29] Yenice, N., Saydam, G., \& Telli, S. (2012). "İlköğretim Öğrencilerinin Fen Öğrenmeye Yönelik Motivasyonların Etkileyen Faktörlerin Belirlenmesi". Ahi Evran Üniversitesi Kırşehir Eğitim Fakültesi Dergisi, 13(2), 231-247.

[30] Yılmaz, H., \& Çavaş, P. H. (2007). Fen öğrenimine yönelik motivasyon ölçeğinin geçerlik ve güvenirlik çalışması. İlköğretim Online, 6 (3), 430-440. Retrieved [Online]: http://ilkogretim-online.org.tr. (02.11.2013)

[31] Zimmerman, B. J. (2000) Attaining self-regulation. In M Kaerts, P.R. Pintrich \& M. Zeidner (Eds). Handbook of Self-Regulation. pp. 13-39. 